\title{
HUBUNGAN ANTARA KUALITAS LAYANAN \\ DAN MINAT MEMBELI PADA KONSUMEN MINI MARKET MINA USWAH SURABAYA
}

\author{
Umi Anugerah Izzati \\ Program Studi Psikologi Universitas Negeri Surabaya \\ e-mail: umianugerah@gmail.com
}

\begin{abstract}
This study examined the relationship between consumers' perception of the customer service quality and their interests to buy in a small retail shop in Surabaya. Sixty consumers in "Mina Uswah" retail shop were recruited as participants. This shop was chosen because the owner has been promoting for years that buying in this place means giving charity as well. Data were analyzed using regression analysis. The result revealed that $R^{2}=0.715$ which means that the service quality variable have $71.5 \%$ of effective contribution to the participants' intention to buy compared to other variables. This study concluded that the customer service quality correlated with the tendency to buy among its consumers.
\end{abstract}

Key words: perception of customer service quality, intention to buy, consumer

\begin{abstract}
Abstrak: Penelitian ini menguji hubungan antara persepsi konsumen terhadap kualitas layanan pelanggan di toko ritel di Surabaya dan minat mereka untuk membeli. Enam puluh konsumen di toko ritel "Mina Uswah" direkrut sebagai partisipan. Toko swalayan ini dipilih karena pemiliknya telah mempromosikan bahwa membeli di tempat itu berarti juga beramal. Data dianalisis menggunakan analisis regresi. Hasil penelitian menunjukkan bahwa $\mathrm{R}^{2}=0,715$ yang berarti bahwa variabel kualitas pelayanan memiliki $71,5 \%$ kontribusi niat peserta untuk membeli dibandingkan dengan variabel lainnya. Penelitian ini menyimpulkan bahwa kualitas layanan yang ditawarkan oleh penjual berkorelasi dengan kecenderungan untuk membeli pada konsumennya.
\end{abstract}

Kata kunci: Persepsi kualitas layanan, minat membeli, konsumen

Dewasa ini perkembangan mini market di Indonesia semakin pesat hingga membuat persaingan di bidang usaha ini menjadi semakin ketat. Dampaknya adalah para konsumen akan semakin kritis dalam memilih tempat berbelanja. Hal inilah yang mendorong setiap mini market untuk bersaing dalam memberikan kepuasan kepada konsumennya.

Salah satu dari sekian banyak mini market tersebut adalah Mini Market Mina. Mini market Mina adalah toko (ritel) yang menyediakan beraneka macam barang-barang kebutuhan sehari-hari. Mini market ini menarik untuk diteliti karena merupakan lini ekonomi dari sebuah panti asuhan yang berada di bawah naungan Yayasan Wachid Hasyim Surabaya. Tujuan didirikannya mini market ini adalah untuk mendapatkan pemasukan penghasilan yang bisa membantu kegiatan di panti asuhan dan sebagai sarana pembelajaran bagi anak-anak yang tinggal di panti asuhan. Anak-anak di Panti Asuhan Khoiriyah Hasyim sejak dini sudah diberikan pembelajaran agar memiliki kemandirian. Salah satu, cara yang diterapkan adalah dengan memberdayakan mereka untuk menjadi bagian di Mini Market Mina. Mereka membantu menjadi kasir atau pramuniaga secara bergantian agar mereka terbiasa untuk mandiri. Oleh karena itu, slogan yang disampaikan di mini market mina adalah "beramal sambil berbelanja". Artinya, bagi konsumen yang ingin beramal dapat dilakukan di Mini Market Mina sambil berbelanja.

Namun, konsumen tentunya akan memilih mini market yang dapat memberikan layanan yang lebih memuaskan, seperti layanan yang diberikan oleh para pegawai 
yang murah senyum, ramah, bersahabat, sopan, sigap atau tanggap, handal, profesional, responsif dan mampu melayani dengan cepat. Kualitas layanan merupakan salah satu unsur penilaian konsumen terhadap perusahaan yang bergerak dalam bidang jasa. Kualitas layanan juga merupakan faktor yang sangat penting yang harus menjadi prioritas utama dalam menyusun strategi pemasaran.

Layanan bertujuan untuk memfasilitasi pembeli saat berbelanja di toko atau gerai atau mini market. Layanan merupakan suatu hal yang harus dilakukan untuk mempermudah konsumen dalam mencari dan memilih produk. Menurut Kasmir (2004) ciri-ciri pelayanan yang baik adalah memiliki karyawan yang baik, adanya sarana dan prasarana yang baik, bertanggung jawab kepada setiap pelanggan sejak awal hingga selesai, memberikan pelayanan yang baik, mampu berkomunikasi, memberikan jaminan kerahasiaan setiap transaksi, memiliki pengetahuan dan kemampuan yang baik, memahami kebutuhan pelanggan, dan memberikan kepercayaan kepada pelanggan.

Pada model kualitas pelayanan (service quality), kualitas jasa didefinisikan sebagai penilaian atau sikap global berkenaan dengan superioritas suatu jasa. Definisi didasarkan pada tiga landasan konseptual utama menurut Martin (2004) yaitu : (1) kualitas jasa lebih sukar dievaluasi konsumen daripada kualitas barang (2) persepsi terhadap kualitas jasa merupakan hasil dari perbandingan antara harapan pelanggan dengan kinerja aktual jasa (3) evaluasi kualitas tidak hanya dilakukan atas hasil jasa, namun juga mencakup evaluasi terhadap proses penjualan barang. Model kualitas pelayanan (service quality) menganalisis gap antara dua variabel yakni layanan yang diharapkan dan layanan yang dipersepsikan/dirasakan. Sebagai pihak yang membeli dan mengkonsumsi layanan, konsumen lah yang menilai tingkat kualitas layanan yang diberikan suatu perusahaan.

Menurut Syah (2004), minat (interest) berarti kecenderungan atau kegairahan yang tinggi atau keinginan yang besar terhadap sesuatu. Minat pembelian ulang adalah perilaku yang muncul sebagai respon terhadap objek. Minat pembelian ulang menunjukkan keinginan pelanggan untuk melakukan pembelian ulang untuk waktu yang akan datang.

Persepsi konsumen terhadap kualitas layanan sebuah toko eceran atau mini market akan dapat memberikan kepuasan bagi konsumen yang kemudian akan menciptakan minat bagi konsumen untuk membeli di mini market tersebut. Menurut Walgito (2004), persepsi merupakan proses pengorganisasian dan penginterpretasian terhadap stimulus yang diterima oleh individu, sehingga merupakan sesuatu yang berarti. Menurut Stanton (2002) persepsi dapat didefinisikan sebagai makna yang kita pertalikan berdasarkan pengalaman masa lalu, stimuli (rangsangan-rangsangan) yang kita terima melalui lima indera. Persepsi kita dibentuk oleh tiga pasang pengaruh yaitu (1) karakteristik dari stimuli (2) hubungan stimuli dengan sekelilingnya (3) kondisi-kondisi di dalam diri kita sendiri.

Persepsi setiap orang terhadap suatu objek akan berbeda-beda. Oleh karena itu, persepsi memiliki sifat subjektif. Persepsi yang dibentuk oleh seseorang diperngaruhi oleh pikiran dan lingkungan sekitarnya. Oleh karena itu, penilaian konsumen terhadap mini market pun dipengaruhi bagaimana mereka memaknai pelayanan yang diterima. Kualitas layanan merupakan pengalaman sadar yang sifatnya subjektif bagi setiap konsumen. Sejalan dengan pendapat Irwanto (2002) bahwa persepsi adalah proses diterimanya rangsang (objek, kualitas, hubungan antargejala, maupun peristiwa) sampai rangsang itu disadari dan dimengerti. Artinya bahwa kualitas merupakan hasil persepsi konsumen terhadap layanan yang diberikan pihak mini market.

Kepuasan konsumen adalah keseluruhan sikap yang ditunjukkan konsumen atas barang atau jasa setelah mereka memperoleh 
dan menggunakannya (Mowen, 2002). Apabila kualitas jauh di bawah harapan, maka mereka akan mengalami ketidakpuasan. Menurut Kotler dan Amstrong (2001) kepuasan pelanggan adalah tingkat perasaan seseorang setelah membandingkan kinerja (hasil) yang dia rasakan dibandingkan dengan persepsi harapannya. Jadi, tingkat kepuasan adalah fungsi dari perbedaan antara kinerja yang dirasakan dengan harapan. Kalau kinerja dibawah harapan, pelanggan kecewa. Kalau kinerja sesuai harapan, pelanggan puas. Kalau kinerja melebihi harapan, pelanggan sangat puas, senang dan gembira.

Menurut Lupiyoadi (2001) dalam menentukan tingkat kepuasan pelanggan, terdapat lima faktor utama yang harus diperhatikan oleh perusahaan yaitu: kualitas produk dan jasa, kualitas pelayanan, emosional, harga, dan biaya. Persepsi konsumen terhadap kualitas layanan inilah yang merupakan penilaian menyeluruh atas keunggulan suatu jasa. Layanan yang berkualitas dapat diwujudkan melalui kinerja aspek-aspek reliability, emphaty, assurance, responsiveness, dan tangibles untuk membangun kepuasan konsumen. Kelima aspek kualitas ini bila diterapkan secara bersama dapat membangun layanan yang berkualitas prima dan memuaskan (Utami, 2004). Persoalannya, apakah ada kaitan antara kualitas layanan terhadap minat membeli pada mini market Mina surabaya mengingat mini market ini juga mempromosikan dirinya sebagai tempat 'beramal' karena pegawaipegawainya sebagian besar adalah remajaremaja yang tinggal di panti asuhan.

\section{METODE}

Penelitian ini menggunakan studi korelasi untuk mengungkap hubungan antara kualitas layanan dan minat membeli konsumen.

\section{Sampel}

Penelitian ini melibatkan 60 konsumen Mini Market Mina USWAH Surabaya berusia antara 20 sampai 50 tahun dan pernah membeli atau berbelanja di mini market tersebut minimal tiga kali. Teknik pengambilan sampel yang digunakan adalah incidental sampling.

\section{Teknikpengumpulan data}

Data penelitian dikumpulkan dengan menggunakan dua buah skala psikologi, yaitu Skala Minat Membeli dan Skala Kualitas Layanan. Skala Minat Membeli terdiri atas 35 aitem, dengan koefisien reliabilitas sebesar 0,900. Adapun Skala Kualitas Layanan terdiri atas 27 item dengan koefisien reliabilitas sebesar 0,874 .

\section{Teknikanalisis data}

Data dianalisis menggunakan analisis regresi sederhana. Semua perhitungan statistik dalam analisis tersebut menggunakan komputasi Statistical Packages for Social Science (SPSS) versi 14.00.

\section{HASIL DAN PEMBAHASAN}

\section{Hasil}

Analisis regresi sederhana menghasilkan koefisien korelasi (rxy) sebesar 0,846 dengan tingkat signifikansi $\mathrm{p}=0,000$ $(\mathrm{p}<0,05)$. Hasil tersebut menunjukkan bahwa terdapat hubungan positif yang signifikan antara kualitas layanan dengan minat membeli konsumen pada mini market mina surabaya. Hasil analisis regresi penelitian menunjukkan R Square sebesar 0,715 artinya kualitas layanan memiliki sumbangan efektif sebesar 71,5 \% terhadap minat membeli konsumen di mini market mina surabaya. Kondisi tersebut menunjukkan bahwa tingkat konsistensi variabel minat membeli konsumen dapat diprediksi oleh variabel kualitas layanan sebesar 71,5\% dan sisanya sebesar 28,5\% ditentukan oleh faktor-faktor lain yang tidak diungkap oleh penelitian ini, antara lain area operasional mini market mina, hadiah, biaya administrasi, teknologi yang dimiliki, dan besarnya pendapatan konsumen. Sedangkan variabel yang dikontrol adalah 
usia, dan seberapa sering membeli di mini market Mina Uswah Surabaya.

\section{Pembahasan}

Sugiarto (1999) mengatakan bahwa baik maupun buruk penilaian terhadap kualitas layanan tergantung pada penyedia jasa dalam memenuhi kebutuhan, keinginan, dan harapan pelanggan secara konsisten. Artinya, apabila layanan yang diterima sesuai dengan layanan yang diharapkan, maka kualitas layanan dipersepsikan positif. Sebaliknya, layanan yang diterima dinilai tidak sesuai dengan harapan, maka pelanggan akan mempersepsikan negatif kualitas layanan tersebut.

Kualitas layanan dikatakan baik apabila penyedia jasa memberikan layanan yang lebih tinggi dari yang diharapkannya. Semakin baik kualitas, maka semakin tinggi pula kepuasan pelanggan. Sebaliknya, bila semakin buruk kualitas maka semakin rendah kepuasan pelanggan. Keith Hunt (Mowen, 2002,) mendefinisikan kepuasan konsumen sebagai "evaluasi yang dilakukan bahwa pengalaman setidak-tidaknya sama baiknya sebagaimana yang seharusnya".

Mardalis (2005) menyimpulkan bahwa kepuasan pelanggan adalah faktor utama yang dapat menarik loyalitas pelanggan. Loyalitas pelanggan perlu diupayakan karena pelanggan yang setia akan aktif berpromosi, memberi rekomendasi kepada keluarga dan sahabatnya, menjadikan produk sebagai pilihan utama, dan tidak mudah pindah pada merek lain. Kepercayaan dan harapan akan membuat pelanggan seolah-olah menggantungkan diri pada pihak penyedia jasa, sehingga dapat menimbulkan komitmen yang kuat dan pembelian secara berulang terhadap penjual yang sama sebagai tanda munculnya minat untuk membeli.

Loyalitas memerlukan minat agar dapat diwujudkan secara riil. Minat mengarahkan perhatian, rasa tertarik, keinginan, dan motif konsumen untuk merealisasikan loyalitas. Loyalitas konsu- men kemudian dapat diwujudkan dengan adanya minat dalam berbagai bentuk, misalnya dengan mulai memperhatikan produk lain yang ditawarkan Mini Market Mina Uswah Surabaya, ketertarikan untuk memberi rekomendasi kepada keluarga dan rekan kerja, dan keinginan untuk menjadikan produk di Mini Market Mina Uswah Surabaya sebagai pilihan utama, serta tidak mudah berpindah pada mini market lain.

Hasil penelitian menunjukkan bahwa saat dilakukan penelitian, konsumen Mini Market Mina Uswah Surabaya memiliki minat membeli yang sangat tinggi. Hal tersebut berarti konsumen memiliki perhatian lebih, ketertarikan, dan keinginan untuk mengetahui lebih dalam lagi tentang mini market mina uswah surabaya baik produk maupun layanannya. Hal ini didukung oleh hasil jawaban pada skala minat membeli konsumen. Hal lain yang terungkap adalah konsumen membeli di mini market mina uswah karena keluarga dan teman juga membeli di sana.

Hasil ini didukung oleh Kristianto (2003) melalui penelitiannya terhadap sikap dan minat membeli masyarakat yang menyimpulkan bahwa sikap mempunyai pengaruh yang signifikan positif terhadap minat untuk membeli. Sikap dibentuk dari hasil evaluasi terhadap suatu objek, stimulus, atau gagasan, yang dalam hal ini adalah evaluasi terhadap stimulus pelayanan yang berkualitas.

Saat penelitian ini dilaksanakan, penilaian konsumen terhadap kualitas layanan mini market mina Uswah Surabaya berada dalam kategori sangat positif dan positif. Perbedaan penilaian ini menunjukkan bahwa persepsi setiap konsumen berbedabeda, meskipun seluruh konsumen mendapatkan layanan yang sama. Hal tersebut membuktikan pernyataan bahwa persepsi bersifat individual.

Tjiptono (2006) menyatakan bahwa kemampuan memberikan layanan yang memuaskan merupakan ciri kehandalan 
penjual. Kehandalan juga merupakan komponen yang penting untuk membangun sebuah pelayanan yang berkualitas dimata konsumen. Menurut Sugiarto (1999) kemampuan memberikan layanan yang cepat mampu menciptakan layanan yang berkualitas. Pernyataan yang mendukung juga dikemukakan oleh Utami (2004) yang menyimpulkan bahwa reliability, emphaty, assurance, responsiveness, dan tangibles secara bersama-sama sangat berpengaruh terhadap kepuasan konsumen. Kepuasan konsumen dapat meningkatkan loyalitas konsumen.

Besarnya sumbangan kualitas layanan terhadap minat membeli konsumen cukup beralasan, karena manusia tidak hanya mengutamakan unsur kuantitas melainkan juga unsur kualitas dari suatu produk. Unsur kuantitas seperti hadiah sifatnya mudah ditiru, sedangkan kualitas dapat menjadi cirri pembeda dengan produk mini market lain. Pernyataan tersebut didukung oleh pendapat Kotler dan Amstrong (2001) bahwa jika konsumen merasa amat puas terhadap kinerja atau hasil suatu produk atau jasa, maka konsumen tersebut akan melakukan pembelian ulang, bahkan lebih jauh lagi akan melakukan promosi kepada kerabat, teman, atau orang terdekatnya agar menggunakan produk atau jasa yang sama.

\section{SIMPULAN}

Terdapat hubungan yang positif dan signifikan antara kualitas layanan dengan minat membeli di mini market mina surabaya. Semakin baik kualitas layanan, maka semakin tinggi minat membeli konsumen. Sebaliknya, semakin buruk kualitas layanan, maka semakin rendah pula minat membeli konsumen. Dapat disimpulkan dari penelitian ini bahwa meskipun suatu mini market mempromosikan dirinya dengan menggunakan alasan-alasan non-ekonomi seperti 'tempat beramal', namun kualitas layanan yang ditawarkan tetaplah menjadi alasan utama bagi konsumen untuk membeli di tempat tersebut.

\section{DAFTAR PUSTAKA}

Irwanto. (2002). Psikologi Umum. Jakarta : PT.Prenhallindo.

Kasmir. (2004). Etika Customer Service. Jakarta : PT. Grafindo.

Kotler, P., dan Amstrong. 2001. Prinsip-Prinsip Pemasaran Jilid 1. Jakarta : Erlangga.

Kristianto, P.L. (2003). Analisis Sikap dan Minat Masyarakat Membeli produk Kerajinan Orang-orang Cacad Fisik di DIY. Jurnal Ekonomi dan Bisnis (Dian Ekonomi), IX (2), 169-181.

Lupiyoadi, Rambat. (2001). Manajemen Pemasaran Jasa, Teori dan Praktek. Edisi Pertama. Jakarta : Salemba Empat.

Mardalis, A. (2005). Meraih Loyalitas Pelanggan. Benefit, IX (2), 111-119.

Martin, William B. 2004. Quality Customer Service. Jakarta: PPM.

Mowen, J.C. \& Michael M. (2002). Consumer Behavior. 4th Edition. London : Prentice Hall International Inc.
Stanton, William J. (2002). Prinsip Pemasaran. Jakarta: Erlangga.

Sugiarto, E. (1999). Psikologi Pelayanan dalam Industri Jasa. Jakarta: PT Gramedia Pustaka Utama.

Syah, M. (2004). Psikologi Pendidikan dengan pendekatan baru. Bandung: Remaja Rosdakarya offset.

Tjiptono, Fandy. (2005). Pemasaran Jasa. Edisi Pertama. Jawa Timar: Bayumedia Publishing.

Utami, A. (2004). Pengaruh Faktor-faktor Kualitas Jasa terhadap Kepuasan Nasabah, Study Kasus di Bank Syariah Mandiri Cabang Surakarta. Jurnal Akuntansi dan Bisnis, IV (1), 48-60.

Walgito, B. (2004). Pengantar Psikologi Umum. Edisi Keempat. Yogyakarta :Andi Offset. 